\title{
Adoption, Importance and Barriers to the Implementation of Contemporary Management Accounting Practices: Evidence from Egypt
}

\author{
Amani Hussein ${ }^{1}$ \\ ${ }^{1}$ Business Department, The British University in Egypt, Cairo, Egypt \\ Correspondence: Amani Hussein, Business Department, The British University in Egypt, Cairo, Egypt \\ Received: November 27, 2017 \\ Accepted: December 15, 2017 \\ Online Published: December 19, 2017 \\ doi:10.5430/afr.v7n1p192 \\ URL: https://doi.org/10.5430/afr.v7n1p192
}

\begin{abstract}
In present times, complexity in the business environment, and advanced technology has intensified the challenges for more management accounting information to meet global competition. Therefore, contemporary management accounting practices (CMAPs), which focus on financial and non-financial information, have emerged to support managers' decision-making processes. This research is aimed at examining the adoption, importance and barriers to the implementation of contemporary management accounting practices. To achieve its objectives, the research conducted a survey and collected data on forty MAPs. The methodology of the study relied on factor analysis to identify and group different variables into the main factors that contribute to MAPs. In terms of MAPs adoption, the results indicated 9 factors: fundamental traditional management accounting practices (TMAPs); control; world class manufacture (WCM); performance evaluation non-financial; budgeting for planning cash flows; contemporary decision support; traditional decision support; planning and capital budget practice. In terms of importance there are 10 factors; benchmarking practices; costing and decision support; fundamental TMAPs; traditional performance evaluation; control; contemporary performance evaluation; budget for planning day to day; WCM -MRP practice; product life cycle practice and performance evaluation - customer satisfaction. The main conclusion was that the relative adoption of TMAPs is higher than CMAPs. However, Egyptian companies are realizing the importance of large number of CMAPs. Moreover, the research revealed that the key barriers limiting the implementation of CMAPs were the length of time it took to change the societal values and practices, the high degree of uncertainty avoidance and the high cost implementing these advanced practices.
\end{abstract}

Keywords: Contemporary management accounting practices, Performance evaluation non-financial, Benchmarking practices, World - class manufacture

\section{Introduction}

In the contemporary world, global competition, scarce resources, change and complexity in the business environment, and advanced technology have intensified the challenges for more objective and detailed management accounting information. Horngren, Datar, and Foster (2006: page 2) refer to management accounting as the process that measures, analyses and reports financial and non-financial information which helps managers make decisions to fulfill the goals of an organization.

A management accounting practice (MAP) is a framework, model, technique or process that enables management accountants to improve performance, facilitate decision-making, support strategic objectives and add value. (CIMA, 2013: page 3). Johnson and Kaplan (1987) considered traditional management accounting practices (TMAPs) as those that were developed before the 1980s including standard costing, variance analysis, return on investment, budgeting, and cost benefit analysis. TMAPs are internally short-term in focus, and financially oriented (Pavlatos and Paggios (2009); Cadez and Guilding (2008)).

TMAPs are no longer seen as adequate and suitable for today's business environment (Ahmad \& Leftesi, 2014). Thus, new management accounting practices have emerged which emphasise not only financial information but also on non-financial information to give a strategic focus to a company's decisions.(Pavlatos \& Kostakis, 2015).These management accounting practices are referred to as contemporary management accounting practices (CMAPs) and interchangeably referred to in the literature as modern, recently developed, new, advanced or innovative management accounting practices (Scapens (2006); Abdel-Kader and Luther (2008); Abdel-Maksoud, Cheffi, and Ghoudi (2016)

CMAPs are considered as those management accounting practices that have the capacity to relate operations, 
processes and/ or activities with strategic outcomes.(Hyvönen, 2005). CMAPs are regarded as being strategically focused. They also focus on both historical and future events and have affected the whole process of management accounting. (Abdel-Kader \& Luther, 2006).To succeed in the dynamic business environment practices such as Just-in-time (JIT), Activity Based Costing (ABC), Total Quality Management (TQM), and target costing would significantly improve the ability of companies to meet global competition (Sulaiman, Nazli Nik Ahmad, \& Alwi, 2004)

A number of CMAPs have been developed across a range of industries. Practices may differ among companies as well as among countries. The reasons for differences might be as a result of historical, cultural, political or sociological differences. (Yalcin, 2012)

A significant body of research has been published focusing on MAPs in developed and developing countries. (Abdel-Kader and Luther (2006); Angelakis, Theriou, and Floropoulos (2010); Rababa'h (2014);Pavlatos and Kostakis (2015);McLellan (2014);Sulaiman et al. (2004)) The results of these researches report an extensive implementation of TMAPs even in the most developed countries and a low implementation of CMAPs.

In Egypt, there were few studies which report contradictory results. Triest and Elshahat (2007) indicated a lack of advanced MAPs in Egypt based on a survey of 40 companies in four sectors. Abdel Maksoud (2011) study found a high level of implementation based on a survey of manufacturing companies in Egypt which was carried out in 2005. Abdel Maksoud (2011) justified the study's results with the Egyptian government's aims to improve the Egyptian trading competitiveness globally and to attract foreign investments. In addition to the European Union's (EU) support to enhance the application of contemporary managerial practices in Egyptian manufacturing firms. Moreover, Mohamed (2013) pointed to some of the motives of adopting CMAPs in Egypt such as the changes required to bring the Egyptian economy into international competition, the development of computer-based production systems, the integration of local and international companies and the emergence of new philosophies of management such as just-in-time.

There is little evidence and a relative lack of knowledge about the current adoption of CMAPs in Egypt which may limit the potential to improve it. Moreover, there has been very little attention paid to the importance of CMAPs and the barriers of its implementation in Egypt. Therefore, this research is expected to contribute significantly to the management accounting literature by filling the gap in prior research and responding to calls of recent research (Triest and Elshahat (2007); Farouk and McLellan (2011);Farouk and Bose (2012))

This research builds on the accumulated findings of prior research, however, it is distinguished from it by the inclusion of a broad list of CMAPs and TMAPs that have not been included in other Egyptian studies and by providing new empirical comprehensions into management accounting practices in Egypt. Therefore, the research contributes to knowledge in this important topic by examining the adoption, importance and barriers to implementation of CMAPs in Egypt.

This research is structured as follows. A literature review is provided in the next section. The research methodology and data collection is then mentioned, followed by results and discussion, and finally the conclusion.

\section{Literature Review}

\subsection{Adoption of Traditional versus Contemporary Management Accounting Practices}

The Chartered Institute of Management Accountants (CIMA) conducted a survey concerning the usage of more than 100 MAPs and was completed by 439 respondents in July 2009. The results showed that management accountants use a number of practices, on average 33, across a range of operational, managerial and strategic functions. The practices used are a mix of traditional and CMAPs. (Ross \& Kovachev, 2009) According to Omar, Abd-Rahman, and Sulaiman (2004) the integration of traditional with new management accounting practices could result in more effective management accounting system.

Several MAPs dominate the literature although they may be grouped differently by different researchers.These studies conducted in UK (Abdel-Kader \& Luther, 2006); Greece (Pavlatos \& Kostakis, 2015) and Vietnam (Ngoc Phi Anh, Nguyen, \& Mia, 2011) investigated and classified them into costing system, budgeting, performance evaluation, information for decision making and strategic analysis. However, there are slight modification in items included in each category or a degree of overlap among them. Table 1 presents a summary of MAPs categories and its items as identified by some of the aforementioned studies. 
Table 1. MAPs in prior research

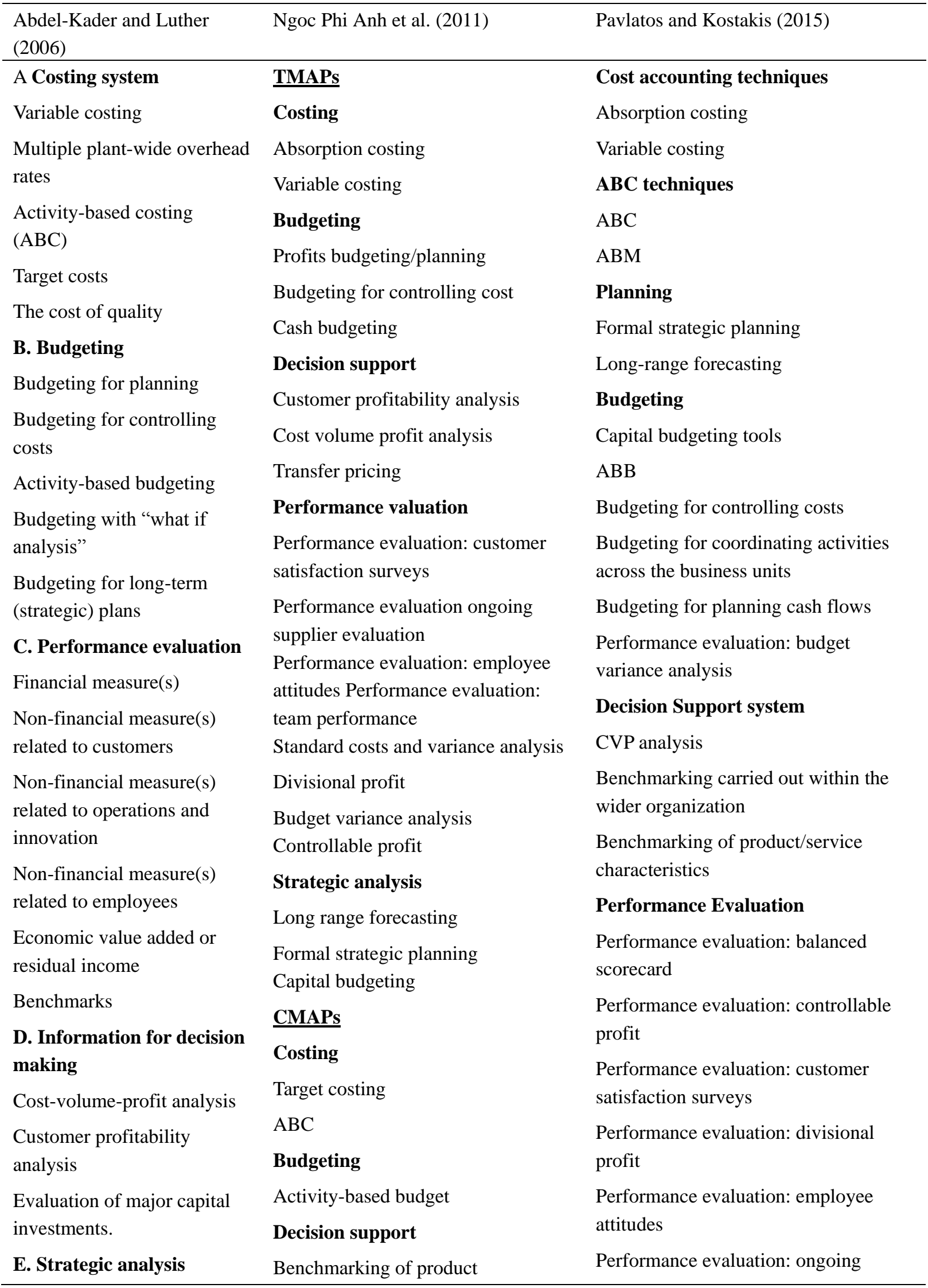




\begin{tabular}{lll}
\hline Long-range forecasting & characteristics & supplier evaluations \\
Value chain analysis & $\begin{array}{l}\text { Benchmarking within the wider } \\
\text { organisations }\end{array}$ & $\begin{array}{l}\text { Performance evaluation: residual } \\
\text { income }\end{array}$ \\
Product life cycle analysis & Benchmarking with outside & Performance evaluation: EVA \\
Analysis of competitors' & organisations & Performance evaluation: ROI \\
strengths and weakness & JIT & Performance evaluation: team \\
& TQM & performance \\
& Activity-based management & Strategic management accounting \\
& Performance valuation & Benchmarking with outside \\
& Non-financial measure(s) & organizations \\
& Economic value added or residual & Value chain analysis \\
income & Product life cycle analysis \\
& Strategic analysis & Target costing \\
& Product life cycle analysis & Customer profitability analysis \\
& Balanced scorecard & Strategic cost management \\
& Value chain analysis & \\
\hline
\end{tabular}

Abdel-Kader and Luther (2006) investigated MAPs in the British food and drinks industry using a list of 38 MAPs and 122 questionnaires completed by management accountants. They found that variable costing, budgeting for planning and for controlling costs, and performance evaluation based on financial measures were widely used however, CMAPs such as activity based costing, activity based budgeting, balanced scorecard and other non-financial performance measures were never or rarely used by 40 per cent of companies.

Ngoc Phi Anh et al. (2011) examined the adoption and benefits of Western management accounting practices (MAPs) in Vietnamese enterprises using questionnaire responses that include a list of 32 MAPs and were obtained from the head or vice-head of the accounting department in 181 enterprises. All of the 16 highest ranked MAPs were traditional practices. By contrast, eight of the nine lowest ranked were CMAPs. Also TMAPs have been perceived as of greater benefit than CMAPs.

A more recent study in Greek Pavlatos and Kostakis (2015) investigated MAPs usage before (2008) and during (2013) the country's economic crisis . They applied factor analysis to summarize and reduce the list of 62 MAPs into fewer factors for both surveys. Their main conclusion revealed that during the crisis there were increased usage of CMAPs such as ABC systems and strategic management accounting practices, while decreased usage of traditional cost accounting practices.

Ismail and Eid (2007) studied the world class manufacture practices (WCM) as an innovative MAPs in Egypt such as Just-in-time (JIT), total quality management (TQM), strategic cost management (SCM) total preventive maintenance (TPM) materials requirement planning (MRP) optimized production technology (OPT) and enterprise resource planning (ERP) implemented by Egyptian companies. The results were: just in time purchasing and production (JIT) was the practice most implemented by the Egyptian companies, followed by TQM and then MRP.

It is difficult to reach conclusions about the use of MAPs in different countries given the range of industries and variation in companies' complexity across the studies. However, a main finding revealed that companies continue to rely more on TMAPs rather than CMAPs (Abdel-Kader and Luther (2006); McLellan (2014); Alleyne and Weekes-Marshall (2011);Sulaiman et al. (2004) ;Armitage, Webb, and Glynn (2016))

This research builds on the accumulated findings of prior research and adopted from a board list of MAPs. It has classified MAPs into four categories based on manager's information needs: (1) cost accounting, (2) planning-budgeting, (3) performance evaluation (4), decision support as shown in appendix1. The following paragraphs cover the most important studies and main conclusion based on these four categories.

\subsubsection{Cost Accounting Practices}

Pierce and O'Dea (2003) study focused on managers' perceptions regarding their information needs and revealed 
interesting finding by which that managers gave higher importance to target costing and ABC. Moreover, Pavlatos and Kostakis (2015) findings emphasized the importance of ABC during the crisis in Greece. However, Abdel-Kader and Luther (2006) who studied the British food and drinks industry indicated a lower level of importance of ABC.

Several studies concluded that ABC and target costing were used at lower rates (Ngoc Phi Anh et al. (2011); Yalcin (2012); Nimtrakoon and Tayles (2015). Moreover, studies conducted in Arab counties confirm the same conclusion (Rababa'h (2014); McLellan and Moustafa (2013)) Furthermore, Pavlatos and Paggios (2009) concluded that traditional absorption costing and variable costing are the most used cost accounting practices.

Studies in Egypt reach different conclusions Triest and Elshahat (2007);Farouk and McLellan (2011) indicated that ABC concepts were unfamiliar. However, Mohamed (2013) applied a case study on one of the leading Egyptian manufactuting companies and found that $\mathrm{ABC}$ was used.

To sum up, although managers need the $\mathrm{ABC}$ and target costing as important information, the studies revealed that they were not adopted as traditional costing practices. Both traditional and contemporary costing practices are included in research MAPs list.

\subsubsection{Planning and Budget Practices}

Several studies conducted have included different types of budgeting practices such as budgeting systems for controlling costs, budgeting system for coordinating activities across the business units, budgeting systems for planning cash flows capital budgeting and budgeting day-today planning of operations. Budgeting practices were the predominate practice in the management control systems of American businesses (McLellan, 2014) and (Abdel-Kader \& Luther, 2006) in UK. Moreover, in other less developed countries such in Ghana (Mbawuni \& Anertey, 2014) Pakistan (Ashfaq, Younas, Usman, \& Hanif, 2014); Vietnamese (Ngoc Phi Anh et al., 2011). In Greece,budgeting for planning financial position, and budgeting for controlling costs have been ranked highly in usage before and during the crisis.(Pavlatos \& Kostakis, 2015). In Egypt, Farouk and Bose (2012) study has found that Egyptian companies make extensive use of budgets, specifically budgeting for controlling costs and budgeting day-today planning of operations.

While the contemporary activity-based budgeting (ABB) is ranked moderately adopted in Ghana (Mbawuni \& Anertey, 2014) in other studies it had a low rank in use as well as importance.( McLellan (2014); Nimtrakoon and Tayles (2015); Ngoc Phi Anh et al. (2011))

Thus, the main conclusion of the majority of the studies was that traditional budget practices are still widely used and important even in the most developed countries.Both traditional and contemporary budgeting practices are included in research MAPs list.

\subsubsection{Performance Evaluation}

Performance evaluation is based on financial and non - financial measures. Financial performance is referred to as the level of profit that represent successful achievement of competitive advantage.(Noordin, Zainuddin, Mail, \& Sariman, 2015). It include some TMAPs such as return (profit) on investment, divisional profit, controllable profit, variance analysis and other CMAPs such as Economic value added (EVA) and residual income.

The majority of the studies acknowledge the high adoption level of performance evaluation based on traditional financial measures (Abdel-Kader and Luther (2006) ;Pavlatos and Paggios (2009);Alleyne and Weekes-Marshall (2011) ; Rababa'h (2014)). Moreover, some studies indicated that they are also highly important (Ngoc Phi Anh et al., 2011) . In contrast, EVA was the least used performance evaluation practice (Mbawuni and Anertey (2014); Ngoc Phi Anh et al. (2011))

On the other hand, non-financial performance is referred to as the superiority achieved compared to competitors in terms of cost advantage, quality, delivery schedule, sales volume, market share and in terms of product innovation. (Noordin et al., 2015) It may include measures related to (employee attitudes, team performance, supplier evaluations customer satisfaction surveys, balanced scorecard) and some add benchmarking.(Abdel-Kader and Luther (2006); Alleyne and Weekes-Marshall (2011)

Pierce and O'Dea (2003) indicated that managers consider non-financial performance measures and benchmarking as satisfying their information needs. While the majority of studies concluded that the balanced scorecard and other non-financial performance practices were perceived to be important but never or rarely used by companies. (Abdel-Kader and Luther (2006); McLellan and Moustafa (2013); McLellan (2014)),some indicated a very often usage (Alleyne and Weekes-Marshall (2011); Mbawuni and Anertey (2014)) or a satisfactory level. (Pavlatos \& Paggios, 2009) 
In Egypt, Farouk and McLellan (2011) concluded the non-financial performance and benchmarking practices are adopted relatively infrequently. However, when Mohamed (2013) studied one leading Egyptian manufacturing company his findings revealed that balanced scorecard and benchmarking were among the practices used.

Therefore, although the majority of the studies support adopting traditional finanacial performance, this research combines benchmarking, financial and nonfinancial performance evaluation to examine the current status of the MAPs in Egypt.

\subsubsection{Decision Making Support}

This section include TMAPs used for decision making such as cost volume profit analysis (CVP) and transfer price. Moreover, some of CMAPs items such as customer profitability analysis, value chain and product life cycle were categorized differently among studies as decision support or as strategic analysis as shown in table 1 . This research combines these items under the decision making category as these strategic analysis support decision making needs and could be under its' umbrella as shown in Appendix1.

Regarding the traditional decision support practices, several studies supported the wide usage of CVP analysis (Ngoc Phi Anh et al. (2011); Alleyne and Weekes-Marshall (2011); Nimtrakoon and Tayles (2015)). Moreover, other studies highlighted the importance of CVP (Abdel-Kader and Luther (2006);Uyar (2010);Pavlatos and Kostakis (2015)) Furthermore, in Egypt Farouk and Bose (2012) and Mohamed (2013) supported the high adoption and importance of CVP analysis. However, transfer pricing practice was found not important in a study conducted by Uyar (2010) in Turkey.

Activity based management (ABM) is considered as a contemporary decision support. Pierce and O'Dea (2003) indicated that managers considered ABM important for their own information needs. However, Rababa'h, (2014) pointed out a lack of usage of contemporary decision making and strategic analysis practices in the Jordanian financial sector. Moreover, other studies indicated low adoption of ABM, value chain, customer profitability analysis and product life cycle analysis (Ashfaq et al. (2014); McLellan (2014))

On the other hand, some studies indicated that some of these CMAPs were widely adopted such as customer profitability analysis (Mbawuni \& Anertey, 2014) product life cycle analysis. (Alleyne and Weekes-Marshall (2011);Ngoc Phi Anh et al. (2011); Mohamed (2013))

Malmadana and Smith (2007) indicated significant differences in both quality management practices and performance reporting systems when total quality management (TQM) was applied. Moreover, Abdel-Kader and Luther (2008) examined the impact of a range of potentially contingent variables on MAPs selected from the UK's largest industry sector. The results revealed that TQM and just in time (JIT) were from the variables that significantly explained the differences in management accounting sophistication. Furthermore, Ngoc Phi Anh et al. (2011) indicated that JIT and TQM were very well known and used in Vietnamese companies.

In Egypt, the same conclusion has been reached in the study conducted by Ismail and Eid (2007) to examine the class manufacture practices (WCM) as an innovative MAPs. They justified adoption of JIT, TQM and MRP in the Egyptian manufacturing companies by the motivation of these companies to gain competitive advantages. Thus, these items were added to MAPs research list as decision support practices.

\subsection{Barriers to Implement CMAPs}

It is claimed that continuous acceptance of TMAPs may be due to availability of information and expertise relating to these practices as opposed to that relating to CMAPs. (Sulaiman et al. (2004);K. Ahmad (2017)). Nimtrakoon and Tayles (2015) indicated that while respondents perceived $A B C$ as beneficial they did not adopt due to lack of expertise to implement. Moreover, Nassar, Al-Khadash, Al-Okdah, and Sangster (2011) in their study in Jordan pointed out that the most impotant reasons for not implementing CMAPs were lack of co-operation between universities (academics) and companies (professionals), lack of conferences, seminars, workshops and lack of local consultants companies. Other reserchers Nuhu, Baird, and Appuhami (2016) suggested training employees as a common practice when adopting CMAPs and to compensate the lack of experience.

Sulaiman et al. (2004) highlighted the importance of top management support. In addition, Yap, Lee, Said, and Yap (2013) emphasized that the most common challenge faced by the companies are the resistance from both middle-level managers and subordinates to decide and adopt new practices.

M. Ahmad and Leftesi (2014) studied the barriers that inhibit the adoption of CMAPs in Libyan companies. The results indicated the following important barriers respectively were: lack of an active professional management accounting society, lack of local training programs about advanced practices, lack of relevant courses on such 
advanced practices in academic institutions, lack of software packages relevant to advanced practices, lack of up-to-date publications about advanced practices and absence of Libyan companies that have adopted advanced practices. However, the least severe barriers were that advanced techniques were too complex, benefits from advanced practices are difficult to observe, and no significant benefits were perceived from adopting advanced practices.

Ismail and Eid (2007) studied the barriers of adopting world class manufacture (WCM) practices. Their findings revealed the following barriers respectively, namely poor planning and lack of knowledge. In addition to the need for cost justification, resistance to change, lack of management support, lack of appropriate monitoring, lack of employee education and training, lack of employee motivation and lack of communication were all barriers for using the WCM practices. They recommended training programs that increase the awareness of the manufacturing companies. Also, they highlighted the role of policy makers in enhancing the capability of manufacturers.

\section{Research Methodology}

\subsection{Data Collection and Management Accounting Practices List}

Management accounting systems' adoption information is not readily available from public sources. Therefore, studying them required designing a tailored research questionnaire.(Davila \& Foster, 2005) Therefore, to achieve its objectives, the research designed a questionnaire and conducted a survey on a sample of seniors or heads of the accounting departments who have the awareness, experience, knowledge and responsibility for the management accounting practices used in their companies. The research needs to capture the opinions of a broad range of management accountants employed in a variety of companies of different sizes and industries operating in Egypt to achieve sufficient sample size. The number of responses received by the study were 171 out of 400 originally sent questionnaires (with a survey response rate of $42.8 \%$ ). This percentage is considered acceptable in such kind of research. (Nimtrakoon \& Tayles, 2015) There were a lot of difficulties in collecting the questionnaires and were completed mainly by frequent personal visits to distribute the questionnaire and take it in after being filled out. The data collection period was more than 10 months ended December 2016 .Many companies did not express any interest in the research and replied that the main reasons for not participating were the lack of time and they did not consider research as top priorities. Table 2 shows the industry type and company age for the research sample.

Table 2. Description of the Sample

\begin{tabular}{lll}
\hline Industry Classification & Frequency & Percent \\
\hline 1.Basic Resources & 1 & 0.6 \\
2.Chemicals & 15 & 8.8 \\
3.Construction and Materials & 25 & 14.6 \\
4.Food and Beverage & 30 & 17.5 \\
5.Industrial Goods and Services and Automobiles & 21 & 12.3 \\
6.Personal and Household Products & 31 & 18.1 \\
7.Real Estate & 6 & 3.5 \\
8.Medical care and medicine & 16 & 9.4 \\
9.Others & 26 & 15.2 \\
Total & $\mathbf{1 7 1}$ & $\mathbf{1 0 0 \%}$ \\
\hline Company Age & & \\
\hline Less than 10 years & 36 & 21.1 \\
10-20 years & 79 & 46.2 \\
More than 20 & 56 & 32.7 \\
Total & $\mathbf{1 7 1}$ & $\mathbf{1 0 0 \%}$ \\
\hline
\end{tabular}

Table 2 presents companies selected in the sample classified according to type of industry. The highest number of companies were in the personal and household products industry while basic resources has the lowest number of companies in the sample. In terms of age, the table indicates that the majority of companies in the sample, about 79\%, have been operating for 10 years or more, which is good indicator on establishment and continuity in the business 
environment. The older the company, the more experience and willingness the company has to develop, use and apply advanced practices.

The sample included different leading companies for example within the food industry were companies manufacturing sweets, dairy and edible oil products. In other industries there were companies that manufacture carpet and home appliances. Moreover, within the pharmaceuticals industry the companies were concerned with medicine production. The Kompass Egypt was the directory used to select the companies and their addresses for each industry type.

The list of MAPs items/variables were adopted from previous studies (Abdel-Kader \& Luther, 2006); Egypt (Ismail \& Eid, 2007);Greece (Pavlatos \& Kostakis, 2015) and Vietnam (Ngoc Phi Anh et al., 2011) to enhance the reliability and validity of the questionnaire. The questionnaire was pre-tested through in-depth discussions with two accounting lecturer and three management accounting professionals to be more consistent with the Egyptian environment. The questionnaire was subsequently revised based on feedback. As a result, a total of 40 MAPs were identified as variables for the factor analysis as shown in Appendixland the explanation for some of these items are shown in the Appendix 2

The questionnaire was initially prepared in English, and subsequently translated into the Arabic language. The questionnaire was validated using "reverse translation". Both English and Arabic versions of the questionnaire were offered to the respondents. The questionnaire presented a list of 40 items aimed at identifying the following: The first section was concerned with the adoption of 40 items either TMAPs or CMAPs in the companies of the sample. Respondents were asked to indicate the adoption of MAPs using a five point Likert-type scale (1 indicating "never" and 5 indicating "very often"). In the second section the respondents were asked to rate the importance of each practice using four point Likert-type (1 indicating "Not important" and 4 "very important"). The third section contains questions about the barriers which limit or impede the use of CMAPs. The barriers list was adopted mainly from (M. Ahmad \& Leftesi, 2014) and (Ismail \& Eid, 2007). The last section related to the industry type and company age.

\subsection{Research Approach}

The survey aimed to measure the accounting professional opinions on the adoption, importance and barriers to implementing management accounting practices. The analysis begins with a descriptive analysis to explore the variables measured by the questionnaire. Moreover, the study employs factor analysis to build a well-defined set of constructs that classify management accounting practices. Factor analysis is used to study multi-dimensional phenomena that involve several attributes or factors and understand the structure among different variables (Field, 2009, p.628). This technique of analysis involves determining the smallest number of factors that can be used to best represent the interrelationships among the set of variables (Pallant, 2010). It is normally used to regroup variables into a limited set of clusters based on shared variance. (Yong and Pearce, 2013). Factor loadings determine the correlation or contribution of each variable to a particular factor; therefore, this helps group variables into factors (Field, 2009, p.631).

The research aimed at examining the adoption, importance and barriers to the implementation of CMAPs. The research was fulfilled through answering the following research questions

Q1: What are the most adopted management accounting practices?

Q2: What are the most important management accounting practices?

Q3: What are the barriers to implementing contemporary management accounting practices?

\section{Results and Discussion}

The research results started with a descriptive analysis to explore the variables measured by the questionnaire as shown in table 3. 
Table 3. Descriptive Statistics Management Accounting Practices adoption

\begin{tabular}{|c|c|c|}
\hline Management Accounting Practices & Mean & Std. Deviation \\
\hline Materials requirement planning (MRP) & 4.12 & 1.14 \\
\hline Performance evaluation based on customer satisfaction surveys & 4.04 & 1.05 \\
\hline Product cost: Absorption costing & 4.01 & 1.16 \\
\hline Enterprise Resource Planning (ERP) & 3.99 & 1.13 \\
\hline Standard costing & 3.96 & 1.17 \\
\hline Activity-based costing (ABC), & 3.80 & 1.34 \\
\hline Cost Volume Profit analysis & 3.75 & 1.26 \\
\hline Product Cost : Variable costing & 3.74 & 1.29 \\
\hline Transfer pricing & 3.70 & 1.40 \\
\hline Budgeting systems for planning cash flows & 3.68 & 1.44 \\
\hline Performance evaluation based on return (profit) on investment & 3.60 & 1.21 \\
\hline Just-in-time (JIT) & 3.52 & 1.43 \\
\hline Total quality management (TQM), & 3.46 & 1.37 \\
\hline Target costing & 3.41 & 1.48 \\
\hline Long range forecasting & 3.35 & 1.21 \\
\hline Capital budgeting techniques & 3.32 & 1.03 \\
\hline Total preventive maintenance (TPM) & 3.30 & 1.44 \\
\hline Performance evaluation based on team performance & 3.25 & 1.18 \\
\hline Benchmarking of product/service characteristics & 3.25 & 1.50 \\
\hline Budgeting systems for controlling costs & 3.23 & 1.48 \\
\hline Benchmarking within the organization & 3.20 & 1.44 \\
\hline Budgeting systems for planning day to day operation & 3.19 & 1.32 \\
\hline Formal strategic planning & 3.16 & 1.16 \\
\hline Benchmarking with outside the organization & 3.12 & 1.49 \\
\hline Performance evaluation based on budget variance analysis & 3.07 & 1.44 \\
\hline Performance evaluation based on divisional profit & 2.95 & 1.54 \\
\hline Performance evaluation based on supplier evaluations & 2.91 & 1.38 \\
\hline Product life cycle analysis & 2.90 & 1.41 \\
\hline Optimized production technology (OPT) & 2.79 & 1.35 \\
\hline Performance evaluation based on employee attitudes & 2.76 & 1.33 \\
\hline Budgeting systems for coordinating activities & 2.73 & 1.37 \\
\hline Customer profitability analysis (CPA) & 2.73 & 1.62 \\
\hline Performance evaluation based on controllable profit & 2.62 & 1.36 \\
\hline Value chain analysis & 2.58 & 1.32 \\
\hline Economic value added (EVA); & 2.51 & 1.23 \\
\hline Performance evaluation based on residual income & 2.48 & 1.27 \\
\hline Strategic cost management (SCM) & 2.33 & 1.26 \\
\hline Activity based budgeting (ABB) & 2.23 & 1.36 \\
\hline Activity based management (ABM) & 2.20 & 1.43 \\
\hline Balanced scorecard (BSC) & 2.11 & 1.25 \\
\hline
\end{tabular}

Table 3 shows the descriptive statistics of the entire sample; mean adoption and standard deviation for the 40 MAPs as respresented from the highest rank to lowest at the end of the table. The table revealed that the majority of the high ranked practices were TMAPs however, MRP (rank 1), performance evaluation based on customer satisfaction surveys (rank 2), ERP (rank 4) and ABC (rank 6) were CMAPs. While the seven of the last ten ranked practices were CMAPs. This results are consistent with the majority of prior studies (Abdel-Kader and Luther (2006); Angelakis et al. (2010); Pavlatos and Paggios (2009); Rababa'h (2014); McLellan (2014) ;Pavlatos and Kostakis (2015)) which reported an extensive implementation of TMAPs even in the most developed countries and a low implementation of CMAPs. 
Table 4. Descriptive statistics of importance of MAPs

\begin{tabular}{|c|c|c|}
\hline Management Accounting Practices & Mean & Std. Deviation \\
\hline Budgeting systems for planning cash flows & 3.64 & 0.63 \\
\hline Materials requirement planning (MRP) & 3.51 & 0.77 \\
\hline Enterprise Resource Planning (ERP) & 3.50 & 0.73 \\
\hline Performance evaluation based on customer satisfaction surveys & 3.49 & 0.77 \\
\hline Product cost: Absorption costing & 3.41 & 0.79 \\
\hline Standard costing & 3.39 & 0.81 \\
\hline Cost Volume Profit analysis & 3.38 & 0.86 \\
\hline Product Cost : Variable costing & 3.30 & 0.83 \\
\hline Budgeting systems for controlling costs & 3.25 & 0.89 \\
\hline Activity-based costing (ABC), & 3.17 & 1.03 \\
\hline Transfer pricing & 3.17 & 0.93 \\
\hline Performance evaluation based on return (profit) on investment & 3.15 & 0.94 \\
\hline Benchmarking of product/service characteristics & 3.12 & 1.02 \\
\hline Long range forecasting & 3.05 & 0.81 \\
\hline Target costing & 3.04 & 0.98 \\
\hline Total quality management (TQM), & 3.04 & 0.93 \\
\hline Benchmarking with outside the organization & 3.02 & 0.99 \\
\hline Capital budgeting techniques & 3.01 & 0.83 \\
\hline Performance evaluation based on team performance & 2.99 & 0.88 \\
\hline Just-in-time (JIT) & 2.98 & 1.01 \\
\hline Formal strategic planning & 2.97 & 0.88 \\
\hline Benchmarking within the organization & 2.91 & 1.08 \\
\hline Product life cycle analysis & 2.91 & 0.95 \\
\hline Total preventive maintenance (TPM) & 2.91 & 0.95 \\
\hline Strategic cost management (SCM) & 2.84 & 0.94 \\
\hline Budgeting systems for planning day to day operation & 2.83 & 0.83 \\
\hline Performance evaluation based on budget variance analysis & 2.75 & 1.11 \\
\hline Budgeting systems for coordinating activities & 2.74 & 0.80 \\
\hline Customer profitability analysis (CPA) & 2.72 & 1.14 \\
\hline Performance evaluation based on supplier evaluations & 2.66 & 1.02 \\
\hline Performance evaluation based on divisional profit & 2.66 & 1.13 \\
\hline Optimized production technology (OPT) & 2.62 & 1.05 \\
\hline Value chain analysis & 2.58 & 0.84 \\
\hline Performance evaluation based on controllable profit & 2.49 & 0.97 \\
\hline Performance evaluation based on employee attitudes & 2.48 & 0.97 \\
\hline Activity based budgeting (ABB) & 2.40 & 0.90 \\
\hline Activity based management (ABM) & 2.34 & 0.88 \\
\hline Performance evaluation based on residual income & 2.33 & 0.83 \\
\hline Economic value added (EVA); & 2.33 & 0.90 \\
\hline Balanced scorecard (BSC) & 2.12 & 0.95 \\
\hline
\end{tabular}

Table 4 revealed the descriptive statistics of the importance of the forty MAPs as respresented from the highest rank to lowest at the end of the table. It represents the ten most important practices for CMAPs with slight variation in rank level (2, 3, 4 and 10). Moreover, of the ten lowest ranked practices eight of these were CMAPs, six practices of the eight CMAPs are the same as practices adopted with slight variations in rank levels. The other two were related to non-financial performance evaluation namely employee attitude (rank 30) and supplier evaluation (rank 26)

Moreover, the TMAPs which are in highest 10 ranked practices such as budgeting systems for planning cash flows, cost volume profit analysis and budgeting systems for controlling costs This result is consistent with some studies that support the importance of these items (Abdel-Kader and Luther (2006); Wu, Boateng, and Drury (2007); Angelakis et al. (2010). This results are in line with Abdel-Kader and Luther (2006) and Ngoc Phi Anh et al. (2011) who 
highlighed that practices that were highly ranked in adoption were also highly ranked in their importance.

To increase simplicity and richness to the research findings, MAPs were further analysed using factor analysis to identify latent factors. The first step is creating a correlation matrix as shown in table 5.

Table 5. Correlation matrix

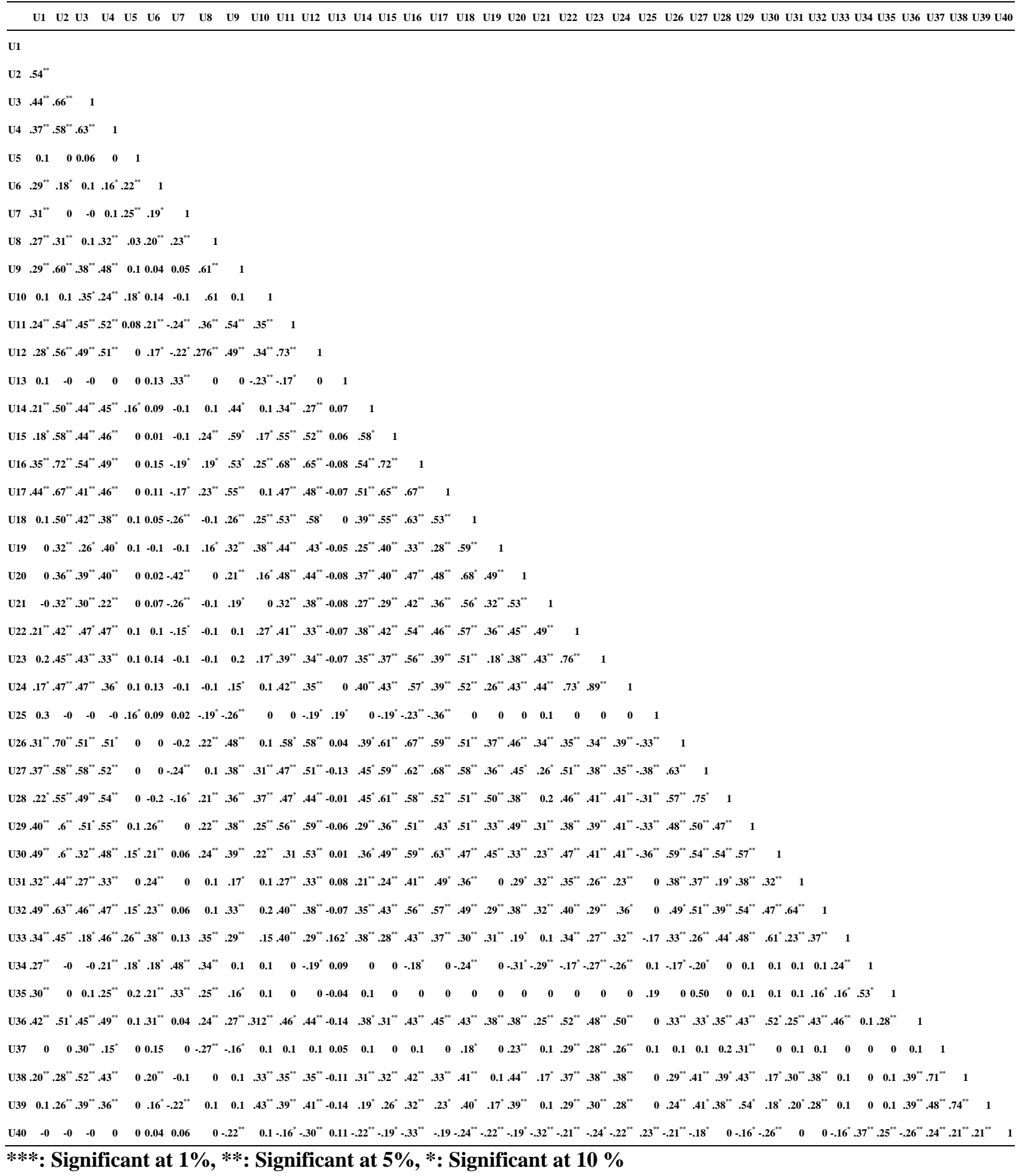

$\mathrm{U} 1$ to $\mathrm{U} 40$ are abbreviations used for the 40 MAPs in the adoption correlation

Table 5 illustrates the existence of significant correlations to a certain limit between the study variables which implies the suitability of applying factor analysis as mentioned by Field, (2009) 
Table 6. "Adoption" Rotated component matrix

\begin{tabular}{|c|c|c|c|c|c|c|c|c|c|c|}
\hline MAPs adoption & 1 & 2 & 3 & 4 & 5 & 6 & 7 & 8 & 9 & 10 \\
\hline Product Cost : Variable costing & 0.86 & & & & & & & & & \\
\hline Cost Volume Profit analysis & 0.80 & & & & & & & & & \\
\hline Formal strategic planning & 0.74 & & & & & & & & & \\
\hline $\begin{array}{l}\text { Benchmarking within the } \\
\text { organization }\end{array}$ & 0.70 & & & & & & & & & \\
\hline $\begin{array}{l}\text { Performance evaluation based on } \\
\text { budget variance analysis }\end{array}$ & 0.67 & & & & & & & & & \\
\hline $\begin{array}{l}\text { Budgeting systems for controlling } \\
\text { costs }\end{array}$ & 0.66 & & & & & & & & & \\
\hline $\begin{array}{l}\text { Performance evaluation based on } \\
\text { divisional profit }\end{array}$ & 0.62 & & & & & & & & & \\
\hline Target costing & 0.62 & & & & & & & & & \\
\hline $\begin{array}{l}\text { Activity based management } \\
\text { (ABM) }\end{array}$ & & 0.88 & & & & & & & & \\
\hline Activity based budgeting (ABB) & & 0.85 & & & & & & & & \\
\hline Balanced scorecard (BSC) & & 0.78 & & & & & & & & \\
\hline $\begin{array}{l}\text { Performance evaluation based on } \\
\text { return (profit) on investment }\end{array}$ & & & 0.73 & & & & & & & \\
\hline Product life cycle analysis & & & 0.70 & & & & & & & \\
\hline $\begin{array}{l}\text { Materials requirement planning } \\
\text { (MRP) }\end{array}$ & & & & 0.87 & & & & & & \\
\hline $\begin{array}{l}\text { Enterprise Resource } \quad \text { Planning } \\
\text { (ERP) }\end{array}$ & & & & 0.80 & & & & & & \\
\hline $\begin{array}{l}\text { Performance evaluation based on } \\
\text { team performance }\end{array}$ & & & & & 0.86 & & & & & \\
\hline $\begin{array}{l}\text { Performance evaluation based on } \\
\text { employee attitudes }\end{array}$ & & & & & 0.84 & & & & & \\
\hline $\begin{array}{l}\text { Performance evaluation based on } \\
\text { supplier evaluations }\end{array}$ & & & & & 0.68 & & & & & \\
\hline $\begin{array}{l}\text { Budgeting systems for planning } \\
\text { cash flows }\end{array}$ & & & & & & 0.62 & & & & \\
\hline Just-in-time (JIT) & & & & & & & 0.83 & & & \\
\hline Total quality management (TQM), & & & & & & & 0.70 & & & \\
\hline Transfer pricing & & & & & & & & 0.83 & & \\
\hline Long range forecasting & & & & & & & & & 0.63 & \\
\hline Capital budgeting techniques & & & & & & & & & & 0.85 \\
\hline Eigenvalues & 13.64 & 3.79 & 3.10 & 2.47 & 1.77 & 1.52 & 1.36 & 1.27 & 1.17 & 1.02 \\
\hline \% of Variance (rotation sum) & 34.10 & 9.47 & 7.75 & 6.17 & 4.41 & 3.81 & 3.39 & 3.19 & 3.19 & 2.56 \\
\hline Cronbach' $\alpha$ & .92 & 92 & .54 & .69 & .84 & NA & .78 & NA & NA & NA \\
\hline
\end{tabular}

SPSS 21 was used to perform the factor extraction on 40 MAPs using the principal component method and varimax rotation. The results of factor analysis revealed that the Kaiser Meyer Olkin (KMO) is equal to .795. The KMO index ranges from 0 to 1 , with .6 suggested as the minimum value for a good factor analysis. (Pallant, 2010).The Bartlett's test of Sphericity $\left(\chi^{2}=4545.001, \mathrm{p}<0.000\right)$ which indicate the suitability of factor analysis and the adequacy of the sample (Field, 2009). 
The criterion for the number of factors to be extracted is based on the eigenvalue. The eigenvalue of a factor represents the amount of the total variance explained by that factor. (Pallant, 2010) Thus, Field, (2009) pointed out that the only factors with large eigenvalues should be retained.

As a result, ten factors were extracted with $77.78 \%$ of the total variance being explained cumulatively. Another criteria to retain the factor is to determine the Cronbach's $\alpha$; value for every factor extracted cut-off point of .7 is suitable. However for survey studies values should not has exceeded the acceptable level (0.6) of reliability (Field, 2009). Based on these criteria table 6 indicates 9 factors only as factor three has been excluded as a result of low Cronbach's $\alpha=0.54$ which is beyond the acceptable level.

The factor loadings are a measurement of the substantive importance of a given variable to a given factor. The closer the communalities are to 1 , the better the factors at explaining the original data. Varimax method tries to load a smaller number of variables highly onto each factor resulting in more interpretable clusters of factors. Therefore, commonalities of greater than 0.6 are included, otherwise the item is excluded on the basis of its low loading (Field, (2009); McLellan and Farouk (2013))

The first factor included the largest number of eight items/variables among the nine factors, with the eigenvalue of 13.64, and accounts for $34.1 \%$ of the total variance being explained. This factor has Cronbach $\alpha=0.92$ indicating very high reliability. It includes eight used practices with the majority of them were TMAPs and two only CMAPs. When classifying these practices it was found that three are related to performance evaluation (two traditional financial measures and benchmarking) and two are related to costing practices (variable costing and target costing). The remaining practices are two related to planning \& budgeting practices (formal strategic planning and budgeting for controlling cost) while one is related to decision support (CVP analysis). This factor represents a group of practices that companies apply together and combines practices from different categories but is consisted mainly form TMAPs. In practice, companies tend to use a number of TMAPs in combination.(Nuhu et al., 2016).Therefore, the researcher labelled this factor fundamental TMAPs. This result indicates that Egyptian companies still rely more on TMAPs and similar conclusion was reached in other studies conducted on other countries Abdel-Kader and Luther (2006) in UK; McLellan (2014) in US ; Pavlatos and Kostakis (2015)in Greece.

This second factor included three CMAPs namely (ABM, ABB and BSC) with an eigenvalue of 3.79, and accounts for $9.47 \%$ of the total variance being explained. This factor has Cronbach $\alpha=0.92$ indicating very high reliability. Maiga and Jacobs (2003) pointed out that activity-based practices are assisting the measurement of all four perspectives of the BSC. Chenhall and Moers (2015) clarified that using ideas from ABM provided managers with an enhanced approach to control. Therefore, the researcher labeled this factor control practices

Factor four include two world class manufacture practices (MRP and ERP). This finding is consistent with Ismail and Eid (2007) study that indicated that MRP is one of the most implemented world class manufacture (WCM) practices by the Egyptian companies. Therefore, the researcher labeled this factor WCM practices.

Factor five included three contemporary nonfinancial performance practices (based on team performance, based on employee attitude and based on supplier evaluation). This is consistent with Abdel Maksoud (2011) who reported the existence of high rates of the implementation of CMAPs. This factor could be labeled contemporary performance evaluation non-financial.

Factor six is only one practice budgeting for planning cash flow. This result is in line with several studies such as Alleyne and Weekes-Marshall (2011) ; Nimtrakoon and Tayles (2015); Pavlatos and Kostakis (2015))that indicated budgeting for planning cash flows as the most widely used practice.

In factor seven two CMAPs namely JIT and TQM. Prior studies such as Ismail and Eid (2007) found JIT and TQM was the practice most implemented by the Egyptian firms. Moreover, Ngoc Phi Anh et al. (2011) indicated that JIT and TQM were very well known and used as decision support practice. Therefore, the researcher labelled this factor contemporary decision support.In the last three factors every factor include only one practice and all are considered traditional. Factor eight is transfer price which is one of the traditional decision support practices. The ninth factor is long range forecasting which could be labelled planning. The last factor is capital budget practice.To sum up the relative adoption of the TMAPs are more than that of CMAPs. While 10 TMAPs were used out of 16 representing $62.5 \%$ practices adopted, 12 CMAPs out of 24 were used representing 50\% practices adopted. Although the relative adoption of TMAPs of the Egyptian companies are higher than CMAPs, the results indicate good step toward implementation of CMAPs. 
Table 7. Correlation matrix

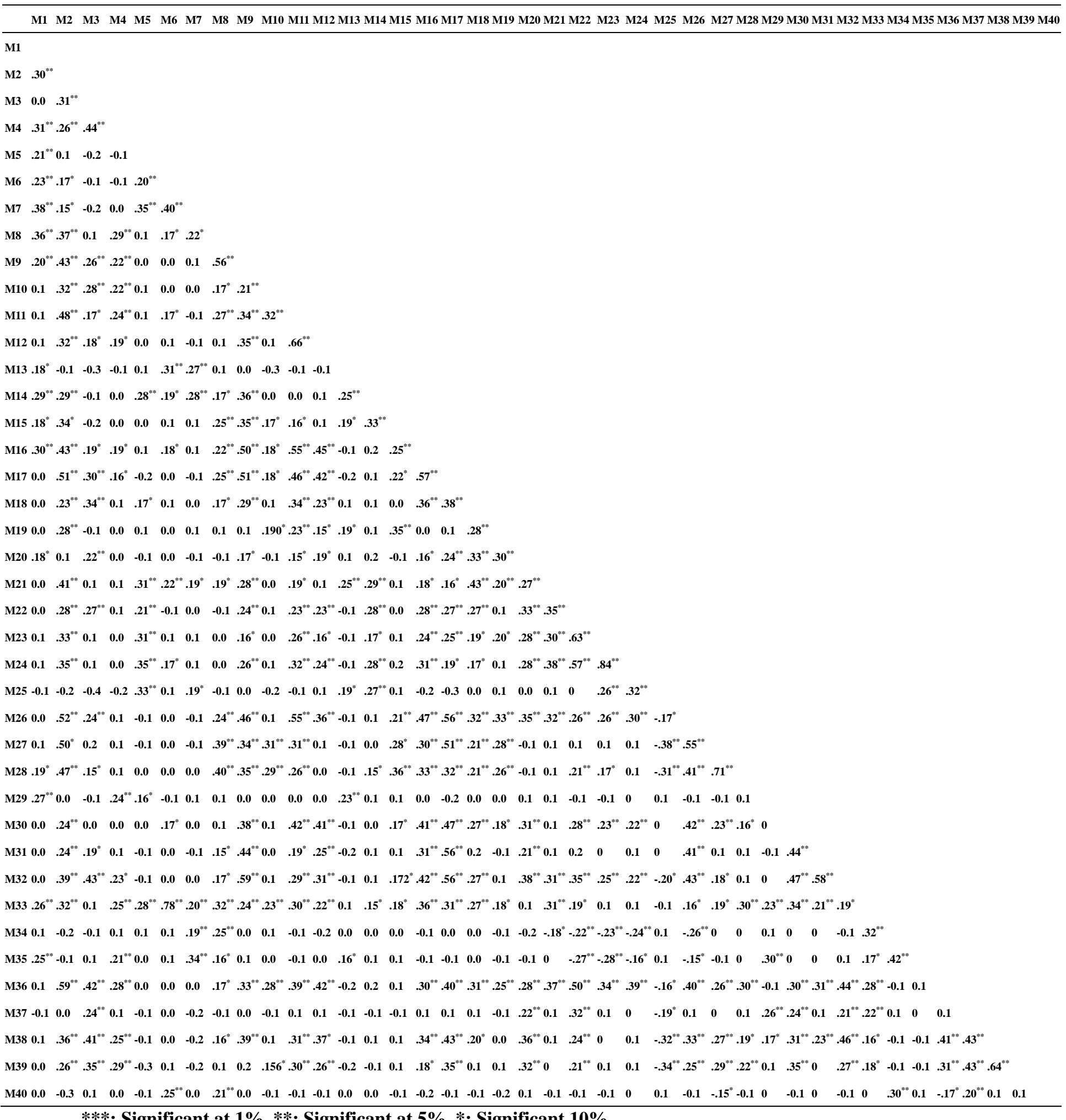
***: Significant at 1\%, **: Significant at 5\%, *: Significant $10 \%$

M1 to M40 are abbreviations used for the 40 MAPs in the importance correlation

Table 7 illustrates the existence of significant correlations to a certain limit between the study variables which implies the suitability of applying factor analysis to examine the importance of MAPs 
Table 8. "Importance"Rotated component matrix

\begin{tabular}{|c|c|c|c|c|c|c|c|c|c|c|c|}
\hline MAPs /Importance & 1 & 2 & 3 & 4 & 5 & 6 & 7 & 8 & 9 & 10 & 11 \\
\hline $\begin{array}{l}\text { Benchmarking of } \\
\text { product/service characteristics }\end{array}$ & 0.88 & & & & & & & & & & \\
\hline $\begin{array}{l}\text { Benchmarking with outside the } \\
\text { organization }\end{array}$ & 0.87 & & & & & & & & & & \\
\hline Just-in-time (JIT) & & 0.83 & & & & & & & & & \\
\hline $\begin{array}{l}\text { Total quality management } \\
\text { (TQM), }\end{array}$ & & 0.77 & & & & & & & & & \\
\hline Product Cost : Variable costing & & 0.66 & & & & & & & & & \\
\hline Target costing & & 0.61 & & & & & & & & & \\
\hline Standard costing & & & 0.73 & & & & & & & & \\
\hline Transfer pricing & & & 0.65 & & & & & & & & \\
\hline Long range forecasting & & & 0.64 & & & & & & & & \\
\hline $\begin{array}{l}\text { Budgeting systems for } \\
\text { planning cash flows }\end{array}$ & & & 0.60 & & & & & & & & \\
\hline $\begin{array}{l}\text { Performance evaluation based } \\
\text { on controllable profit }\end{array}$ & & & & 0.82 & & & & & & & \\
\hline $\begin{array}{l}\text { Performance evaluation based } \\
\text { on divisional profit }\end{array}$ & & & & 0.81 & & & & & & & \\
\hline $\begin{array}{l}\text { Activity based management } \\
\text { (ABM) }\end{array}$ & & & & & 0.90 & & & & & & \\
\hline $\begin{array}{l}\text { Activity based budgeting } \\
\text { (ABB) }\end{array}$ & & & & & 0.87 & & & & & & \\
\hline Balanced scorecard (BSC) & & & & & 0.65 & & & & & & \\
\hline $\begin{array}{l}\text { Performance evaluation based } \\
\text { on supplier evaluations }\end{array}$ & & & & & & 0.75 & & & & & \\
\hline $\begin{array}{l}\text { Performance evaluation based } \\
\text { on employee attitudes }\end{array}$ & & & & & & 0.73 & & & & & \\
\hline $\begin{array}{l}\text { Performance evaluation based } \\
\text { on team performance }\end{array}$ & & & & & & 0.70 & & & & & \\
\hline $\begin{array}{l}\text { Budgeting systems for } \\
\text { planning day to day operation }\end{array}$ & & & & & & & 0.83 & & & & \\
\hline Value chain analysis & & & & & & & & 0.72 & & & \\
\hline Economic value added (EVA); & & & & & & & & 0.62 & & & \\
\hline $\begin{array}{l}\text { Materials requirement } \\
\text { planning (MRP) }\end{array}$ & & & & & & & & & 0.78 & & \\
\hline Product life cycle analysis & & & & & & & & & & 0.76 & \\
\hline $\begin{array}{l}\text { Performance evaluation based } \\
\text { on customer satisfaction } \\
\text { surveys }\end{array}$ & & & & & & & & & & & 0.85 \\
\hline Eigenvalues & 8.96 & 4.05 & 2.89 & 2.57 & 1.99 & 1.73 & 1.63 & 1.57 & 1.42 & 1.33 & 1.33 \\
\hline$\%$ of Variance (rotation sum) & 22.40 & 10.14 & 7.22 & 6.43 & 4.97 & 4.33 & 4.07 & 3.93 & 3.54 & 3.33 & 2.89 \\
\hline Cronbach' $\alpha$ & 0.83 & 0.82 & 0.63 & 0.80 & 0.87 & 0.75 & NA & 0.55 & NA & NA & NA \\
\hline
\end{tabular}


Table 8 shows the MAPs importance factors. The results of factor analysis revealed that the Kaiser Meyer Olkin (KMO) is equal to .663 .The Bartlett's test of Sphericity $\left(\chi^{2}=3510.518, \mathrm{p}<0.000\right)$ which indicate the suitability of factor analysis and the adequacy of the sample (Field, 2009).It revealed 11 factors with detailed information for every factor eigenvalues, percentage of variance and Cronbach' $\alpha$. The table shows that factor eight was excluded due to low Cronbach' $\alpha=0.55$. Therefore, there are 10 factors only.

In terms of importance the first factor included two practices related to benchmarking which is considered CMAPs. The researcher labelled it benchmarking practices. The second factor include 4 practices three are CMAPs and one TMAPs (variable costing) it combine between costing practices (target costing and variable costing) and decision support (JIT and TQM) Thus, this factor could be labelled costing and decision support practices. This result supports the conclusion reached by Pierce and O'Dea (2003) indicating that managers consider target costing as one of highest information needs.

The third factor included 4 practices which were all TMAPs from different categories; costing, planning \& budgeting, and decision support. The researcher labelled it fundamental TMAPs.

Moreover, the fourth factor is consisted of two financial performance and could be labelled traditional performance evaluation practices.

Factor five shows three practices ABM, ABB and BSC the same as in table 6 and could be labelled control practices. Also factor six include three CMAPs related to nonfinancial performance and could be labelled contemporary performance evaluation. In factor seven traditional budget for planning day to day is considered important. However the last three factors each include one practice and they are all CMAPs. The factors could be labelled WCM -MRP practice, product life cycle practice and performance evaluation - customer satisfaction.

To summarize the relative importance of the TMAPs are less than the CMAPs. While 8 TMAPs of the total 16 practices $(50 \%)$ were considered important, the 14 CMAPs of total 24 total practices $(58.3 \%)$ were considered important. It appears that the Egyptian companies realize the importance of large number of CMAPs however, there still high adoption of TMAPs.

Therefore, it is important to examine the factors or barriers that could limit or impede the implementation of CMAPs. Table 9 revealed the barriers means and standard deviations.

Table 9. Barrier to the Adoption of Advanced MAPs

\begin{tabular}{lcr}
\hline Barrier to the Adoption of Advanced MAPs & Mean & $\begin{array}{c}\text { Std. } \\
\text { Deviation }\end{array}$ \\
\hline It takes longer time to change the societal values and practices & 3.94 & 1.13 \\
High degree of uncertainty avoidance & 3.88 & 1.15 \\
High cost to implement these advanced practices & 3.81 & 1.15 \\
Lack of financial resources & 3.80 & 1.14 \\
Lack of local training programs about advanced practices & 3.74 & 1.36 \\
Lack of relevant courses on such advanced practices in academic institutions & 3.62 & 1.28 \\
Lack of software packages relevant to advanced practices & 3.53 & 1.28 \\
Lack of relevant employee skills because of insufficient training provided by the & 3.48 & 1.23 \\
company & 3.46 & 1.26 \\
Lack of an active professional management accounting society & 3.07 & 1.14 \\
These advanced practices are too complex & 2.96 & 1.25 \\
No significant problems with current system & 2.89 & 1.21 \\
Benefits from advanced practices are difficult to observe & &
\end{tabular}

Table 9 shows 12 barriers adopted from prior studies that the research has revealed. The key barriers limiting the implementation of CMAPs were: the long time it takes to change the societal values and practices (rank 1), the high degree of uncertainty avoidance (rank2), high cost to implement these advanced practices (rank3) and lack of financial resources (rank 4). The least barriers were: benefits from advanced practices are difficult to observe (rank 12); no significant problems with current system (rank 11) and these advanced practices are too complex (rank10). This result is consistent with Ismail and Eid (2007) findings in Egypt that revealed that the need for cost justification, and 
resistance to change are important barriers. Moreover, Farouk and McLellan (2011) clarified that conservative attitudes of Egyptian managers and non-awareness may limit the usage of CMAPs.

To summarize, although Egyptian companies are at a good stage than before regarding usage and awareness of the value and importance of these CMAPs but there is still a room for improvement.

\section{Conclusion}

Complexity in the business environment, and advanced technology has intensified the challenges for more management accounting information to meet global competition. Therefore, contemporary management accounting practices have emerged to focus on financial and non-financial information to support the decision making of managers.

The research has been aimed at examining the adoption, importance and barriers to the implementation of CMAPs. This research may develop knowledge and contribut to the literature by providing both a theoretical framework and empirical evidence on CMAPs in Egypt, a subject which has received little attention in the management accounting literature to date.

The research has combined a list of forty MAPs, subdivided them into four categories based on managers information needs: (1) cost accounting, (2) planning-budgeting, (3) performance evaluation (4), decision support.

The descriptive research findings indicate in total that TMAPs were found to be slightly higher implemented than the CMAPs. Moreover, that MAPs with high levels of importance tended to be highly adopted. This results are in line with Abdel-Kader and Luther (2006) and Ngoc Phi Anh et al. (2011)

To increase simplicity, but also the comperhensiveness of the research findings factor analysis were applied. In terms of MAPs adoption, the results indicated 9 factors: fundamental TMAPs; control; WCM; performance evaluation non-financial; budgeting for planning cash flows ; contemporary decision support; traditional decision support; planning and capital budget practice. The relative adoption of the TMAPs are more than that of CMAPs. The budget practices were often adopted consistent with prior studies. Although the adoption of TMAPs in Egyptian companies are higher than CMAPs, results indicated significant progress towards implementation of CMAPs.

In terms of importance there are 10 factors; benchmarking practices; costing and decision support; fundamental TMAPs; traditional performance evaluation; control; contemporary performance evaluation; budget for planning day to day; WCM -MRP practice, product life cycle practice and performance evaluation - customer satisfaction. To conclude the performance evaluation; financial, non- financial and benchmarking) are the dominating practices in term of importance. It seems that the Egyptian companies are realizing the importance of large number of CMAPs

The research examined the barriers that could limit the implementation of CMAPs and revealed that the highest barriers limiting the implementation of CMAPs were: the time taken to change societal values and practices (rank 1), the high degree of uncertainty avoidance ( rank2), the high cost to implement these advanced practices (rank3) and lack of financial resources (rank 4).In order to reduce some of these barriers Ismail and Eid (2007) suggested that policy makers in the Egyptian industrial sector should enhance the capability of manufacturing that are willing to implement WCM practices through increased funding, grants, incentives, and educational programs. There is an important role of accounting education in preparing students to be qualified management accountants in the future. Practitioners should be aware of the benefits of CMAPs and how it can improve companies' performance.

No research is without certain caveats. Applying the survey method poses some limitation. Scapens (2006) pointed out that the personalities and backgrounds of key individuals can affect the choice of management accounting practices. Moreover, cross-sectional studies reflects the current status thus it may be difficult to capture the use of dynamic MAPs. Thus, longitudinal research is needed. Factor analysis has its limitations as well. First, the results of factor analysis depend on how well the factors used in analysis are defined and measured. Second, as indicated by Trninić, Jelaska and Štalec (2013), empirical studies are usually indecisive about factors that should be included to measure different latent variables (Trninić, Jelaska and Štalec, 2013, p.13). Future research can apply interviews and cross-country comparisons to provide rich information. Furthermore, a study of the impact of adopting CMAPs on performance can enrich future research. 


\section{References}

Abdel-Kader, M., \& Luther, R. (2006). Management accounting practices in the British food and drinks industry. British Food Journal, 108(5), 336-357. https://doi.org/10.1108/00070700610661321

Abdel-Kader, M., \& Luther, R. (2008). The impact of firm characteristics on management accounting practices: A UK-based empirical analysis. The British Accounting Review, 40(1), 2-27. https://doi.org/10.1016/j.bar.2007.11.003

Abdel-Maksoud, A., Cheffi, W., \& Ghoudi, K. (2016). The mediating effect of shop-floor involvement on relations between advanced management accounting practices and operational non-financial performance indicators. The British Accounting Review, 48(2), 169-184. https://doi.org/10.1016/j.bar.2015.10.002

Abdel Maksoud, A. (2011). Management accounting practices and managerial techniques and practices in manufacturing firms: Egyptian evidence. International Journal of Managerial and Financial Accounting, 3(3), 237-254. https://doi.org/10.1504/IJMFA.2011.041756

Ahmad, K. (2017). The implementation of management accounting practice and its relationship with performance in Small and Medium Enterprises sector. International Review of Management and Marketing, 7(1).

Ahmad, M., \& Leftesi, A. (2014). An exploratory study of the level of sophistication of management accounting practices in Libyan manufacturing companies. International Journal of Business and Management, $2(2), 1$.

Alleyne, P., \& Weekes-Marshall, D. (2011). An exploratory study of management accounting practices in manufacturing companies in Barbados. International Journal of Business and Social Science, 2(10).

Angelakis, G., Theriou, N., \& Floropoulos, I. (2010). Adoption and benefits of management accounting practices: Evidence from Greece and Finland. Advances in accounting, 26(1), 87-96. https://doi.org/10.1016/j.adiac.2010.02.003

Armitage, H. M., Webb, A., \& Glynn, J. (2016). The Use of Management Accounting Techniques by Small and Medium - Sized Enterprises: A Field Study of Canadian and Australian Practice. Accounting Perspectives, 15(1), 31-69. https://doi.org/10.1111/1911-3838.12089

Ashfaq, K., Younas, S., Usman, M., \& Hanif, Z. (2014). Traditional Vs. Contemporary Management Accounting Practices and its Role and Usage across Business Life Cycle Stages: Evidence from Pakistani Financial Sector. International Journal of Academic Research in Accounting, Finance and Management Sciences, 4(4), 104-125.

Cadez, S., \& Guilding, C. (2008). An exploratory investigation of an integrated contingency model of strategic management accounting. Accounting, organizations and society, 33(7), 836-863. https://doi.org/10.1016/j.aos.2008.01.003

Chartered Institute of Management Accountants (2013): Essential Tools For Management Accountants The tools and techniques to support sustainable business success. CIMA cgma.org.1-120

Chenhall, R. H., \& Moers, F. (2015). The role of innovation in the evolution of management accounting and its integration into management control. Accounting, Organizations and Society, 47, 1-13. https://doi.org/10.1016/j.aos.2015.10.002

Davila, A., \& Foster, G. (2005). Management accounting systems adoption decisions: evidence and performance implications from early-stage/startup companies. The Accounting Review, 80(4), 1039-1068. https://doi.org/10.2308/accr.2005.80.4.1039

Farouk, S., \& Bose , S. (2012). Management Accounting Practices in Egypt and China: A Comparative Study. Journal of Accounting, Ethics and Public Policy, 13(4).

Farouk, S., \& McLellan, J. D. (2011). Management accounting practices in Egypt-a transitional economy country. Paper presented at the Cambridge Business \& Economics Conference.

Field, A. (2009). Discovering statistics using SPSS: Sage publications.

Hansen, D., \& Mowen, M. (2013) .Cornerstones of Cost management. Cengage Learning, Second Edition

Horngren, C., Datar,S., \& Foster,G. (2006) Cost Accounting: A Managerial Emphasis. Pearson Education, Inc , Twelfth Edition

Hyvönen, J. (2005). Adoption and benefits of management accounting systems: evidence from Finland and Australia. Advances in International Accounting, 18, 97-120. https://doi.org/10.1016/S0897-3660(05)18005-2 
Ismail , S., \& Eid, R. (2007). The implementation of world class manufacturing techniques in Egyptian manufacturing firms: An empirical study. Industrial Management \& Data Systems, 107(4), 551-566. https://doi.org/10.1108/02635570710740698

Johnson, H. T., \& Kaplan, R. S. (1987). The Rise and Fall of Management Accounting [2]. Strategic Finance, 68(7), 22. https://doi.org/10.1109/EMR.1987.4306297

Maiga, A. S., \& Jacobs, F. A. (2003). Balanced scorecard, activity-based costing and company performance: an empirical analysis. Journal of Managerial Issues, 283-301.

Malmadana , A., \& Smith, M. (2007). Management practices and performance reporting in the Sri Lankan apparel sector. Managerial Auditing Journal, 22(3), 303-318. https://doi.org/10.1108/02686900710733161

Mbawuni, J., \& Anertey, A. R. (2014). Exploring Management Accounting Practices in Emerging Telecommunication Market in Ghana. Accounting and Finance Research, 3(4), 71. https://doi.org/10.5430/afr.v3n4p71

McLellan, J. D. (2014). Management Accounting Theory and Practice: Measuring the Gap in United States Businesses. Journal of Accounting, Business \& Management, 21(1).

McLellan, J. D., \& Farouk, S. (2013). Strategy and Management Accounting Practices Alignment and its affect on Organizational Performance. Journal of Accounting-Business \& Management, 20(1), 1-27.

McLellan, J. D., \& Moustafa, E. (2013). An exploratory analysis of management accounting practices in the Arab Gulf Cooperative countries. Journal of Islamic Accounting and Business Research, 4(1), 51-63. https://doi.org/10.1108/17590811311314285

Mohamed, F. A.-A. (2013). Changes in the business environment and the level of management accounting practices in Egypt: A case study. Journal of American Science, 9(10), 78-89.

Nassar, M., Al-Khadash, H., Al-Okdah, S., \& Sangster, A. (2011). The implementation of management accounting innovations within the Jordanian industrial sector: the role of supply-side factors. European Journal of Economics, Finance and Administrative Sciences, 35, 72-85.

Ngoc Phi Anh, D., Nguyen, D.-T., \& Mia, L. (2011). Western management accounting practices in Vietnamese enterprises: Adoption and perceived benefits. Pacific Accounting Review, 23(2), 142-164. https://doi.org/10.1108/01140581111163971

Nimtrakoon, S., \& Tayles, M. (2015). Explaining management accounting practices and strategy in Thailand: A selection approach using cluster analysis. Journal of Accounting in Emerging Economies, 5(3), 269-298. https://doi.org/10.1108/JAEE-02-2013-0012

Noordin, R., Zainuddin, Y., Mail, R., \& Sariman, N. K. (2015). Performance outcomes of strategic management accounting information usage in Malaysia: insights from electrical and electronics companies. Procedia Economics and Finance, 31, 13-25. https://doi.org/10.1016/S2212-5671(15)01127-2

Nuhu, A., Baird, K., \& Appuhami, R. (2016). The Association between the Use of Management Accounting Practices with Organizational Change and Organizational Performance Advances in Management Accounting (pp. 67-98): Emerald Group Publishing Limited.

Omar, N., Abd-Rahman, I., \& Sulaiman, S. (2004). Management accounting in Malaysia-Has relevance been lost. Accountants Today, November, 26-28.

Pallant, J. (2010) SPSS Survival Manual A Step By Step Guide To Data Analysis Using SPSS, McGraw-Hill Education

Pavlatos, O., \& Kostakis, H. (2015). Management accounting practices before and during economic crisis: Evidence from Greece. Advances in accounting, 31(1), 150-164. https://doi.org/10.1016/j.adiac.2015.03.016

Pavlatos, O., \& Paggios, I. (2009). Management accounting practices in the Greek hospitality industry. Managerial Auditing Journal, 24(1), 81-98. https://doi.org/10.1108/02686900910919910

Pierce, B., \& O'Dea, T. (2003). Management accounting information and the needs of managers: Perceptions of managers and accountants compared. The British Accounting Review, 35(3), 257-290. https://doi.org/10.1016/S0890-8389(03)00029-5 
Rababa'h, A. (2014). The Implementation of Management Accounting Innovations" The Case of Balanced Scorecard Implementation within Jordanian Manufacturing Companies". International Review of Management and Business Research, 3(1), 174.

Ross, L., \& Kovachev, I. (2009). Management accounting tools for today and tomorrow. Chartered Institute of Management Accountants, London Google Scholar.

Scapens, R. W. (2006). Understanding management accounting practices: A personal journey. The British Accounting Review, 38(1), 1-30. https://doi.org/10.1016/j.bar.2005.10.002

Sulaiman, M. b., Nazli Nik Ahmad, N., \& Alwi, N. (2004). Management accounting practices in selected Asian countries: a review of the literature. Managerial Auditing Journal, 19(4), 493-508. https://doi.org/10.1108/02686900410530501

Triest, S., \& Elshahat, M. (2007). The use of costing information in Egypt: a research note. Journal of Accounting \& Organizational Change, 3(3), 329-343. https://doi.org/10.1108/18325910710820328

Trninić, V., Jelaska, I., \& Štalec, J. (2013). Appropriateness and limitations of factor analysis methods utilized in psychology and kinesiology: Part II. Fizička kultura, 67(1), 1-17. https://doi.org/10.5937/fizkul1301001T

Uyar, A. (2010). Cost and management accounting practices: A survey of manufacturing companies. Eurasian Journal of Business and Economics, 3(6), 113-125.

Wu, J., Boateng, A., \& Drury, C. (2007). An analysis of the adoption, perceived benefits, and expected future emphasis of western management accounting practices in Chinese SOEs and JVs. The International Journal of Accounting, 42(2), 171-185. https://doi.org/10.1016/j.intacc.2007.04.005

Yalcin, S. (2012). Adoption and benefits of management accounting practices: an inter-country comparison. Accounting in Europe, 9(1), 95-110. https://doi.org/10.1080/17449480.2012.664394

Yap, K., Lee, T., Said, J., \& Yap, S. (2013). Adoption, Benefits and Challenges of Strategic Management Accounting Practices: Evidence from emerging market. Asia Pacific Management Accounting Journal, 8(2).

Yong, A. G., \& Pearce, S. (2013). A beginner's guide to factor analysis: Focusing on exploratory factor analysis. Tutorials in quantitative methods for psychology, 9(2), 79-94. https://doi.org/10.20982/tqmp.09.2.p079 
Appendix 1

Management Accounting Practices List

\section{TMAPs}

\section{Planning \& Budgeting Practices}

Budgeting systems for planning cash flows

Budgeting systems for controlling costs

Budgeting systems for coordinating activities

Budgeting systems for planning day to day operation

Capital budgeting techniques

Long range forecasting

Formal strategic planning

\section{Costing Practices}

Standard costing

Product cost: Absorption costing

Product Cost :Variable costing

Performance Evaluation

Performance evaluation based on return (profit) on

investment

Performance evaluation based on divisional profit

Performance evaluation based on controllable profit

Performance evaluation based on budget variance

analysis

\section{Decision Support}

Transfer pricing

Cost Volume Profit analysis

\section{CMAPs}

\section{Costing practices}

Activity-based costing (ABC),

Target costing

\section{Budgeting}

Activity based budgeting (ABB)

\section{Decision Making support}

Value chain analysis

Product life cycle analysis

Activity based management (ABM)

Just-in-time (JIT)

Total quality management (TQM),

Strategic cost management (SCM)

Total preventive maintenance (TPM)

Materials requirement planning (MRP)

Optimized production technology (OPT)

Enterprise Resource Planning (ERP) 


\section{Performance Evaluation}

Performance evaluation based on residual income

Economic value added (EVA);

Balanced scorecard (BSC)

Performance evaluation based on team performance

Performance evaluation based on supplier evaluations

Performance evaluation based on customer satisfaction surveys

Performance evaluation based on employee attitudes

Benchmarking within the organization

Benchmarking with outside the organization

Benchmarking of product/service characteristics

\section{Appendix 2}

This appendix is adopted from (Hansen, and Mowen, 2013) book.

Activity Based Costing (ABC) a cost accounting system that uses both unit-and non-unit based cost drivers to assign costs to cost objects by first tracing costs to activities and then tracing costs from activities to products.

Activity based management (ABM) an advanced control system that forces management's attention on activities with the objective of improving the value received by the customer and the profit received by providing this value.

Balanced Scorecard a strategic - based performance management system that typically identifies objectives and measures for four different perspectives: the financial perspective, the customer perspective, the process perspective and the learning and growth perspective.

Benchmarking uses best practices as the standard for evaluating activity performance.

Economic value added (EVA) the after tax operating profit minus the total annual cost of capital.

Enterprise resource planning (ERP) software that has the objective of providing an integrated system capability - a system that can run all the operations of a company and provide access to real time data from the various function areas of a company.

Just in time (JIT) a demand -pull system that strives to produce a product only when it is needed and only in the quantities demanded by customers.

Product life cycle the time a product exists from conception to abandonment; the profit history of the product according to four stages: introduction, growth, maturity, and decline.

Strategic cost management the use of cost data to develop and identify superior strategies that will produce a sustainable competitive advantage.

Target Cost a method of determining the cost of a product or service based on the price the customers are willing to pay.

Total quality management a philosophy that requires managers to strive to create an environment that enable workers to manufacture perfect (zero - defects) products.

Value chain analysis identifying and exploiting internal and external linkages with the objective of strengthening a firm's strategic position. 